DOI: https://doi.org/10.15407/techned2018.04 $: \underline{019}$

\title{
DETERMINATION THE ELECTRICAL POTENTIAL OF A CREATED GROUNDING DEVICE IN A THREE-LAYER GROUND
}

Journal

Publisher

ISSN

Issue

Pages
Tekhnichna elektrodynamika

Institute of Electrodynamics National Academy of Science of Ukraine 1607-7970 (print), 2218-1903 (online)

No 4, 2018 (July/August)

$19-24$

\section{Authors}

\section{D.G. Koliushko*, S.S. Rudenko**}

National Technical University «Kharkiv Polytechnic Institute»,

Kyrpychova st., 2, Kharkiv, 61002, Ukraine,

e-mail:nio5_molniya@ukr.net

* ORCID ID : http://orcid.org/0000-0003-3112-4260

** ORCID ID : http://orcid.org/0000-0002-2544-1545

\section{Abstract}

The work is devoted to the definition of analytical expressions for the electric field potential created by a system of grounding devices of arbitrary configuration taking into account a three-layer geoelectrical structure. The potential is determined on the basis of the solution of the problem of the potential of a point source of current, taking into account the linear distribution of the current along the length of the electrode, and also the method of analogy between the electrostatic field and the field created by a quasi-constant current source. The total potential of the grounding system is determined using the superposition principle of the fields. Analytic 
expressions are obtained for the determination of the potential at an arbitrary observation point created by the field of a solitary electrode. The received expressions allow to calculate the grounding devices without application of the equivalent method and to determine their normalized parameters for the vast majority of power objects of Ukraine with the voltage class of 35-750 kV. The application of the analytical solution makes it possible to significantly improve the accuracy of calculating the electric potential in comparison with models based on the methods of optical analogy or finite differences. References 11, figure 1, table 1.

Key words: grounding device, electrical potential, a three-layer soil, rated parameters, a point source of current.

Received: 22.03.2018

Accepted: 02.04 .2018

Published:

\section{References}

1. Test and control devices, electrical grounding. Standard instruction. SOU

31.2-21677681-19:2009. Kyiv, Minpalyvenerho Ukrainy, 2010. 54 p. (Ukr)

2. IEEE Std 81-2012 Guide for Measuring Earth Resistivity, Ground Impedance, and Earth Surface Potentials of a Grounding System. New York, IEEE, 2012. 86 p.

3. Zubov K.N. Improved computational methods for lightning protection and grounding devices in heterogeneous soil: author's abstract of Can. tech. sci. diss. 05.09.03. Lipetskii gosudarstvennyi tekhnicheskii univer-sitet. Vologda. 2011. 158 p. (Rus)

4. Koliushko D.G. Improving the diagnosis of grounding devices elektroenergoobektov: author's abstract of Can. tech. sci. diss: 05.11.13. Natsionalnyi Tekhnichnyi Universytet Kharkivskyi Polytekhnichnyi Instytut. Kharkiv. 2003. 172 p. (Rus)

5. Uma U.U., Uzoechi L.O., and Robert B.J. Optimization design of ground grid mesh of 132/33 
kv substation using Etap. Nigerian Journal of Technology. 2016. 35.4. Pp. 926-934.

6. Koliushko D.G., Rudenko S.S. Analysis of electrophysical characteristics of grounds in the vicinity electrical substation of Ukraine. Electrical engineering \& electromechanics. 2015. No 3. Pp. 63-66. DOI:

https://doi.org/10.20998/2074-272X.2015.3.10

7. Koliushko D.G., Rudenko S.S. Mathematical model of grounding connection of a power plant with under layer. Elektronnoe modelirovanie. 2014. No 2. Pp. 89-97. (Rus)

8. Shishigin S.L. Development of methods for the analysis and synthesis of electromagnetic fields of electrical devices with high currents: author's abstract of Dr. tech. sci. diss: 05.09.05. Sankt-Peterburgskii gosudarstvennyi politekhnicheskii universitet. Sankt-Peterburg. 2010. 217 p. (Rus)

9. Korovkin N.V., Shishigin S.L. Computational methods in the theory of grounding. Nauchno-te khnicheskie vedomosti Sankt-Peterburgskogo gosudarstvennogo politekhnicheskogo universiteta . 2013. No 1. Pp. 74-79. (Rus)

10. Borisov R.K., Gorshkov A.V., Zharkov Yu.V., Kolechitskiy E.S., Shamshetdinov K.L. The grounding system of electrical installations (regulatory requirements, calculation, design, construction: Handbook. Moskva. Izdatelskii dom MEI. 2013. 360 p. (Rus)

11. Koliushko D.G., Rudenko S.S. Electric field of a point source of current in the ground with a three-layer structure. Elektronnoe modelirovanie. 2011. No 6. Pp. 101-111. (Rus) 